\title{
CLIMATIC CHANGE IN A HIGH-ALTITUDE ALPINE AREA SUGGESTED BY THE ISOTOPIC COMPOSITION OF COLD BASAL GLACIER ICE
}

\author{
by \\ R. Lorrain \\ (Faculté des Sciences, Université Libre de Bruxelles, CP 160, Avenue F. Roosevelt, 50, B-1050 \\ Bruxelles, Belgium) \\ and \\ W. Haeberli \\ (Versuchsanstalt für Wasserbau, Hydrologie und Glaziologie, ETH-Zentrum, CH-8092 Zürich,
} Switzerland)

\section{ABSTRACT}

For the first time, a cold ice cover of a summit in the central Swiss Alps has been sampled from the surface to the bed for determining its isotopic composition in $\delta D$ and $\delta^{18} \mathrm{O}$. Results of the analyses show a striking decrease of $\delta$-values with depth. The $\delta$-value differences are greater than those explicable by a direct temperature effect, but a substantial increase in melt water percolation through the firn since the formation of the deepest ice layer may explain the situation of this high-altitude ice.

\section{INTRODUCTION}

Most isotopic studies dealing with high-altitude parts of Alpine glaciers have so far been based on shallow firn and ice cores which do not reach the bed (Ambach and others, 1972; Jouzel and others, 1977; Oeschger and others, 1977; Schotterer and others, 1977, 1978; Stichler and others, 1982; Haeberli and others, 1983; Oerther and others, 1985) and, hence, can hardly give paleoclimatic information concerning time intervals reaching back more than a few years or decades. In this paper results of isotopic analyses in SD and $\delta^{18} \mathrm{O}$ are given for ice samples from a tunnel reaching the bed in the highest part of Titlisgletscher (Swiss Alps) at an altitude of $3020 \mathrm{~m}$ a.s.1. This exploratory sampling was carried out with particular emphasis on the very basal part. Additional values were obtained from a shallow core drilled from the surface above the tunnel. Questions are raised whether and how the results are interpretable from a paleoclimatic point of view.

\section{SITE DESCRIPTION}

The investigated ice mass is the ice cover of the Chli Titlis, a secondary summit of the Titlis near Engelberg, central Swiss Alps. The site is easily accessible by cable-car and the ice tunnel has been constructed by the cable-car company as a tourist attraction (Fig. 1). Glaciological studies, mainly carried out during consulting work for a governmental (PTT) radio tower on top of the mountain, included seismic refraction soundings on the geometry of the ice/rock-interface and the distribution of firn layers, thermal drilling, bore hole and tunnel temperature measurements, finite element modelling, and stake measurements near the bergschrund (Haeberli and others, 1979; Haeberli and Alean, 1985). The ice summit itself is a perennial corniche, consisting of well-layered ice roughly $25 \mathrm{~m}$ thick

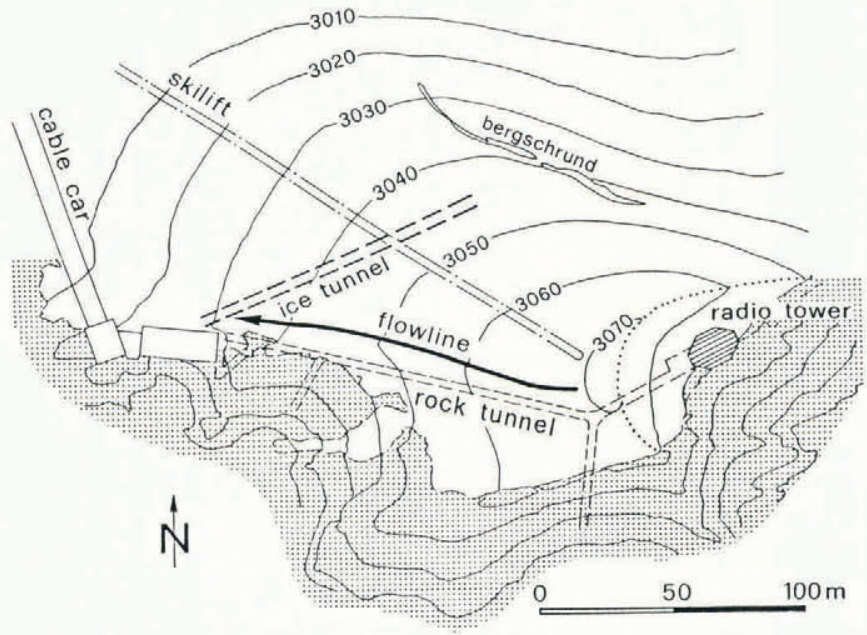

Fig. 1. Topographic situation at Chli Titlis; flowline indicates assumed particle path leading to the sampling place at the entrance of the ice tunnel.

with a $15 \mathrm{~m}$ temperature of $-0.7^{\circ} \mathrm{C}$. Firn thickness increases downslope from 0 to about $15 \mathrm{~m}$ above the bergschrund. Subglacial permafrost temperatures, as measured in the rock tunnel connecting the cable-car station with the radio tower, increase steadily from about $-1.5^{\circ} \mathrm{C}$ at the entrance on the north side to $-0.5^{\circ} \mathrm{C}$ at the tower (rock wall exposed to the south, Fig. 2). Temperatures in the ice tunnel for tourists vary slightly around $-1{ }^{\circ} \mathrm{C}$ at the entrance, which is practically identical with the rock tunnel entrance, approaching melting point towards the bergschrund with increasing ice and firn overburden. Melt water percolation through crevasses in the bergschrund zone can be observed at the end of the ice tunnel. During construction of the rock tunnel, a rather gradual transition from debris-laden basal ice to ice-rich rock could be observed in places. Ice flow velocities at the surface are close to $1 \mathrm{~m} \mathrm{a}^{-1}$. Sliding at the cold and dry bed above the bergschrund is assumed to be negligible.

\section{SAMPLING}

Samples were taken in the ice tunnel, near the entrance, where glacier thickness is a few metres only and 


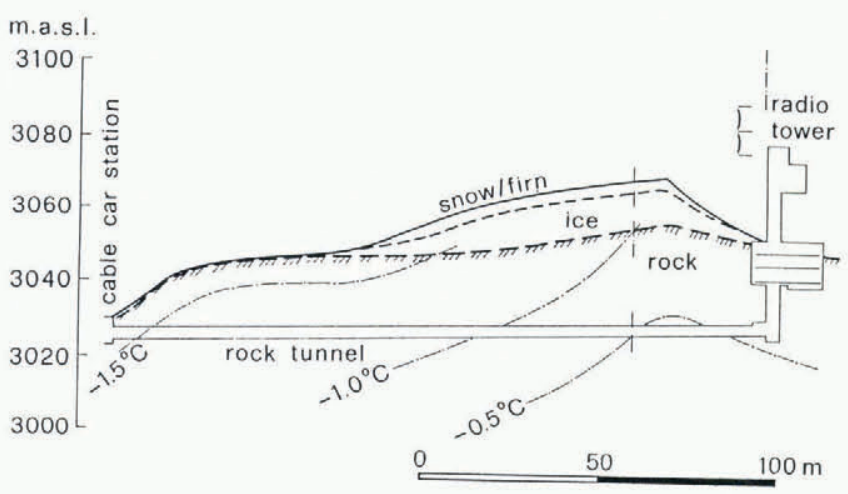

Fig. 2. Section through the summit of Chli Titlis along rock tunnel; permafrost temperatures were measured during tunnel construction and later in a bore hole through the ice summit.

a firn layer is absent. The ice contains about five air bubbles per $\mathrm{cm}^{3}$, some of them spherical with a diameter of $0.2-0.5 \mathrm{~mm}$ but most of them elongated, reaching lengths of about $15 \mathrm{~mm}$. Fine mineral particles appear concentrated in sparse planes intersected by the tunnel walls but are more numerous and dispersed in the very basal layers.

Three types of samples were taken:

(1) A half cubic metre block of ice was cut from the very bottom of the tunnel wall about $15 \mathrm{~m}$ from the entrance at the only place where the bedrock was detected. From this block, different parts, a few cubic decimetres each, were cut in order to be stored at $-20^{\circ} \mathrm{C}$ in portable freezers after being packed in plastic bags.

(2) On the opposite wall at a more easily accessible place, five stainless steel coring cylinders were hammered into

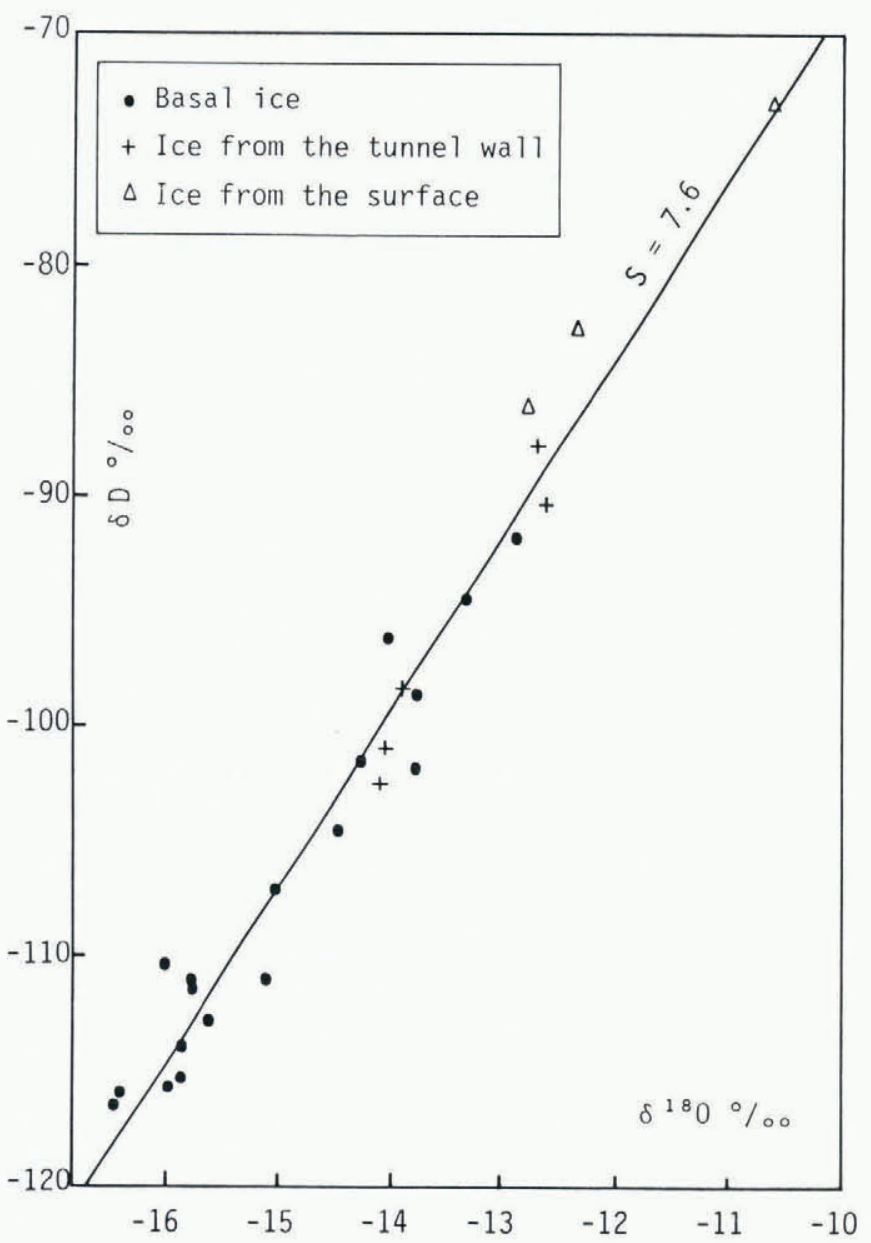

Fig. 3. Isotopic composition in $\delta D$ and $\delta^{18} \mathrm{O}$ of the ice samples. $\mathrm{S}$ is the slope of the linear regression line for the 26 samples. the ice, regularly spaced from the bottom to the top of the wall, along the same vertical. Ice samples of $25 \mathrm{~cm}^{3}$ were transferred into fitted polyethylene bottles and also stored in a freezer. Before these two samplings, about $0.2 \mathrm{~m}$ of the tunnel wall was removed. Moreover, any contact with liquid water was carefully avoided.

(3) A $1 \mathrm{~m}$-long ice core was taken with a CRREL auger from the glacier surface at a spot estimated to be above the second sampling site of the tunnel. The core was cut in three parts, put in plastic bags and stored in a freezer. All these original pieces of ice were resampled in a cold room to avoid contamination. At the present stage, 26 samples have been taken and analysed at the Centre d'Etudes Nucleaires de Saclay in France. The accuracy of the measurements is $0.5 \%$ for $8 D$ and $0.1 \%$ for $\delta^{18} \mathrm{O}$.

\section{ANALYTICAL RESULTS}

The results of the isotopic analyses are presented on a graph in which $\delta^{18} \mathrm{O}$ is plotted against $8 \mathrm{D}$ (Fig. 3). The 26 samples show a linear relationship with a slope $S=7.6$ and a correlation coefficient of 0.98 . This linear relationship is assimilable to the meteoric water line defined by Craig (1961). A slope value near 8 is considered in the literature as valid for ice which has not been submitted to major isotopic changes since its formation (Dansgaard and others, 1973). A second graph (Fig. 4) presents the $\delta D$ and $\delta^{18} \mathrm{O}$ values versus depth. This figure reveals a general trend for the $\delta$-values to become less and less negative from the bottom towards the surface of the glacier with a shift of about $30 \%$ in $8 \mathrm{D}$ and of about $3.5 \%$ in $\delta^{18} \mathrm{O}$. From a closer examination of the graph, it can also be seen that a great part of the shift takes place within the deepest $20 \mathrm{~cm}$, i.e. just above bedrock. In the lowest $10 \mathrm{~cm}$ of the ice, the $\delta$-values indeed cluster around $-115 \%$ in $8 \mathrm{D}$ and $-16 \%$ in $\delta^{18} \mathrm{O}$ whereas, just $10 \mathrm{~cm}$ above, they average $-92.5 \%$ and $-13 \%$ respectively; a particularly sharp gradient is evident.
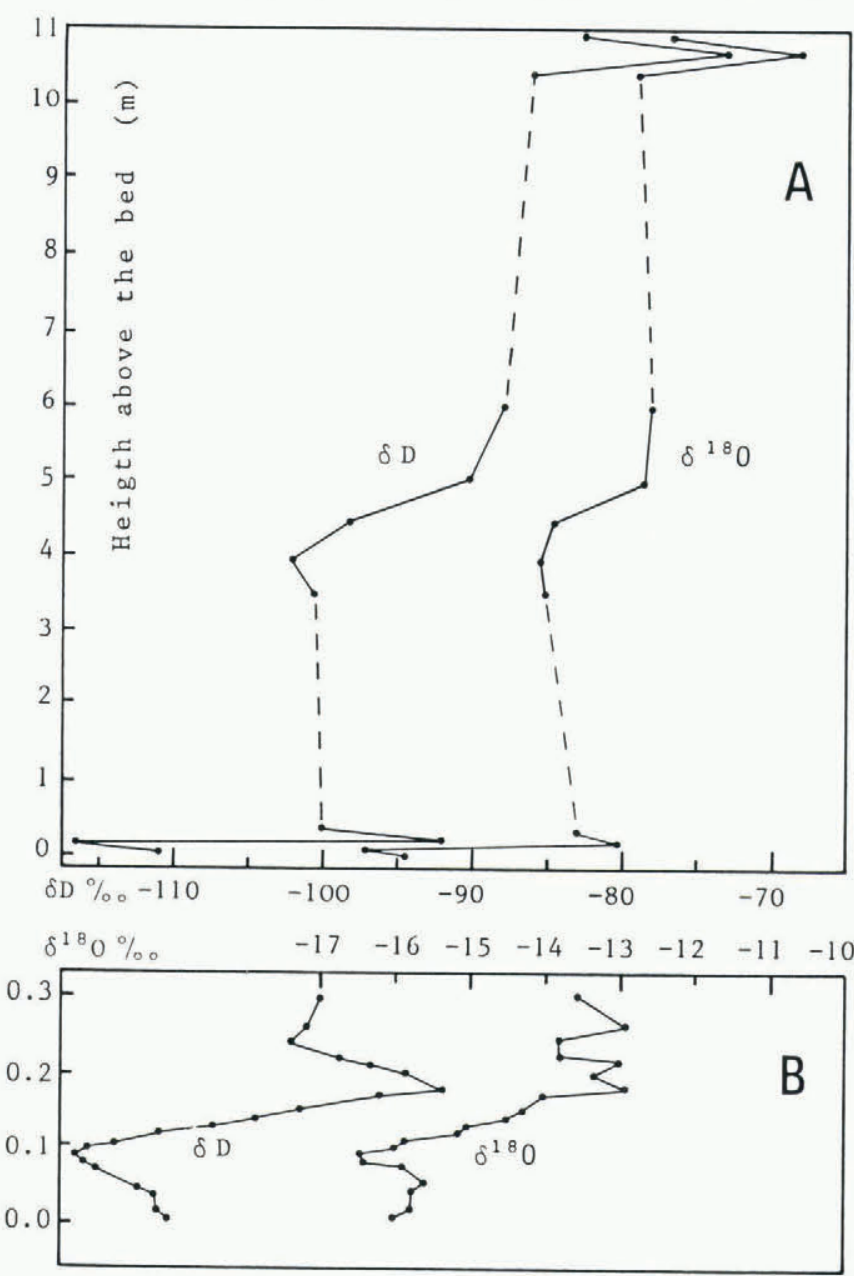

Fig. 4.A: Isotopic profiles observed at the tunnel site of Titlisgletscher. B: Enlargement of the basal zone just above bedrock. 


\section{DISCUSSION}

The increase of the $\delta$-values from the botttom to the surface of the glacier as indicated above suggests a temperature rise since the formation of the deepest ice. Indeed, there is a direct relationship between temperature and $\delta$-values. Theoretical considerations (Dansgaard, 1964) and data from the Mont Blanc Massif in the Alps (Jouzel and others, 1984) suggest that isotopic gradients of 4 to $6 \%$ per ${ }^{\circ} \mathrm{C}$ in $\delta \mathrm{D}$ and of 0.5 to $0.75 \%$ per ${ }^{\circ} \mathrm{C}$ in $\delta^{18} \mathrm{O}$ can be considered normal. Interpreting the isotopic shifts observed at Titlis according to these gradients implies a rise of 4.5 to $7^{\circ} \mathrm{C}$ in mean air temperature since the formation of the oldest ice sampled. Only rough estimates of minimum and maximum possible age of this transition can be derived from flow considerations. With a flowline length of $100-$ $150 \mathrm{~m}$ perpendicular to the surface contours and, hence, along the marginal part of the ice, and an average surface velocity of 0.5 to $1 \mathrm{~m} \mathrm{a}^{-1}$, perfect plasticity with $\mathrm{n} \rightarrow \infty$ yields a lower bound value of 100 years; pure deformation with $\mathrm{n}=1$ and basal layer thickness $=1 / 20$ to $1 / 50$ the total ice thickness gives several thousand years. It therefore appears that the age of the oldest ice should be counted by centuries if not millennia, but is probably Holocene rather than (late-) Pleistocene. The climatic changes known for the period in question are comparable to 20 th-century warming (0.5 to $1{ }^{\circ} \mathrm{C}$, cf. Gamper and Suter, 1982; Haeberli, 1990) and cannot account for temperature changes by several ${ }^{\circ} \mathrm{C}$. Moreover, the fact that the measured $\delta$-values correspond to the meteoric water line and, hence, show no evidence of basal melting and regelation along the flowpath further confirms that Neoglacial/Holocene variations of ice geometry and englacial temperatures must have been weak.

With increasing air temperature, however, percolation of melt water through snow and firn also increases and this may explain part of the observed isotopic shifts. There is indeed a change in the isotopic composition of melt water as it percolates through a snow-pack giving rise to a positive isotopic shift in the remaining snow. This process, which has been studied by Árnason (1969) and Búason (1972) also explains the homogenization of the isotope content within the snow cover which is being transformed into glacier ice. Árnason $(1969,1981)$ compared two places in the firn area of Vatnajökull. In a place with abundant melt-water percolation, a positive shift of about $11.5 \%$ in $\delta \mathrm{D}$ was observed in the firn below the last summer surface whereas no shift was noticeable in a place where percolation was very limited. Árnason concluded that the only way to explain the enrichment in the first case is to assume that the isotopic change occurs as the snow-pack recrystallizes. Moreover, he also proved by an experiment that the greater the proportion of the snow-pack which melts and produces percolating melt water, the greater is the positive shift mentioned above.

Other authors also have mentioned comparable isotopic shifts in the Alps. Ambach and others (1972) studied firn cores in the temperate accumulation zone of Kesselwandferner. They observed the same type of isotopic shifts between the upper layers and the deeper ones, the latter being about $2 \%$ less negative in $\delta^{18} \mathrm{O}$. The same authors also attributed a prominent role to melt water percolation in that situation, arguing that the value of the shift is lower in the highest part of the accumulation area than in the lower part. Moreover, Martinec and others (1977) have studied a snow-pack with a lysimeter at Weissfluhjoch. They observed a shift of about 20\% in $6 \mathrm{D}$ within the lowest snow layer of the snow-pack between mid January when no percolation occurred and mid June when percolation was very effective. They noticed that this particular shift occurred without any change in the $\delta \mathrm{D} / \delta^{18} \mathrm{O}$-ratio, indicating that it cannot be due to evaporation effects.

\section{CONCLUSIONS}

In the ice of the high Alpine area of Titlisgletscher investigated here, isotopic shifts greater than those capable of explanation by direct temperature effect are observed. A substantial increase in melt water percolation since the formation of the deepest ice layer may help to explain the situation. The interpretation of isotopic shifts in terms of paleotemperature must thus be considered with caution in such environments. A quantitative treatment of the problem based on Búason's model (1972) would certainly be worthwhile but, unfortunately, cannot be carried out here because of the lack of information on the isotopic composition of present-day snow, rain water and melt water at the spot. Due to site modification by cableway construction, determination of representative flow and balance parameters is hardly possible today. The observed isotopic shift is nevertheless an interesting phenomenon and deserves further investigation at comparable sites.

\section{ACKNOWLEDGEMENTS}

Thanks are due to D. Gerber of the Engelberg-Titlis cable-car company for facilities given to the authors while sampling at the site, Dr J. Jouzel who made the isotopic analyses possible, Prof. R. Souchez who kindly made critical comments on the first draft of the paper, and Dr J.-L. Tison for his helpful participation to the ice sampling and for stimulating discussions.

\section{REFERENCES}

Ambach, W., H. Eisner, and K. Pessl. 1972. Isotopic oxygen composition of firn, old snow and precipitation in Alpine regions. Z. Gletscherkd. Glaziolgeol., 8(1-2), 125-135.

Árnason, B. 1969. The exchange of hydrogen isotopes between ice and water in temperate glaciers. Earth Planet. Sci. Lett., 6(6), 423-430.

Árnason, B. 1981. Ice and snow hydrology. In Gat, J.R. and R. Gonfiantini, eds. Stable isotope hydrology, deuterium and oxygen-18 in the water cycle. Vienna, International Atomic Energy Agency, 143-175. (Technical Series 210.)

Búason, T. 1972. Equation of isotope fractionation between ice and water in a melting snow column with continuous rain and percolation. J. Glaciol., 11(63), 387-405.

Craig, H. 1961. Isotopic variations in meteoric waters. Science, 133, 1702-1703.

Dansgaard, W. 1964. Stable isotopes in precipitation. Tellus, 16(4), 436-468.

Dansgaard, W., S.J. Johnsen, H.B. Clausen, and N. Gundestrup. 1973. Stable isotope glaciology. Medd. Gronl. 197(2), 1-53.

Gamper, M. and J. Suter. 1982. Postglaziale K limageschichte der Schweizer Alpen. Geogr. Helv., 37(2), 105-114.

Haeberli, W. 1990. Glacier and permafrost signals of 20thcentury warming. Ann. Glaciol., 14, 99-101.

Haeberli, W. and J. Alean. 1985. Temperature and accumulation of high altitude firn in the Alps. Ann. Glaciol., 6, 161-163.

Haeberli, W., A. Iken, and H. Siegenthaler. 1979. Glaziologische Aspekte beim Bau der FernmeldeMehrzweckanlage der PTT auf dem Chli Titlis. Eidg. Tech. Hochschule, Zürich. Versuchsanst. Wasserbau, Hydrol. Glaziol. Mitt., 41, 59-75.

Haeberli, W., U. Schotterer, D. Wagenbach, H. HaeberliSchwitter, and S. Bortenschlager. 1983. Accumulation characteristics on a cold, high-Alpine firn saddle from a snow-pit study on Colle Gnifetti, Monte Rosa, Swiss Alps. J. Glaciol., 29(102), 260-271.

Jouzel, J., L. Merlivat, and M. Pourchet. 1977. Deuterium, tritium and $B$ activity in a snow core taken on the summit of Mont Blanc (French Alps). Determination of the accumulation rate. J. Glaciol., 18(80), 465-470.

Jouzel, J., M. Legrand, J.F. Pinglot, M. Pourchet, and L. Reynaud. 1984. Chronologie d'un carottage de $20 \mathrm{~m}$ au col du Dôme (Massif du Mont Blanc). Houille Blanche, 6/7, 491-497.

Martinec, J., H. Moser, M.R. de Quervain, R. Rauert, and W. Stichler. 1977. Assessment of processes in the snowpack by parallel deuterium, tritium and oxygen-18 sampling. International Association of Hydrological Sciences Publication 118 (Symposium at Grenoble 1975 - Isotopes and Impurities in Snow and Ice), 220-231.

Oerter, H., D. Baker, W. Stichler, and W. Rauert. 1985. 
Isotope studies of ice cores from a temperate Alpine glacier (Vernagtferner, Austria) with respect to the meltwater flow. Ann Glaciol., 7, 90-93.

Oeschger, H., U. Schotterer, B. Stauffer, W. Haeberli, and H. Röthlisberger. 1977. First results from Alpine core drilling projects. Z. Gletscherkd. Glaziologeol., 13(1/2), 1977, 193-204.

Schotterer, U., and 7 others. 1977. Isotope measurements on firn and ice cores from Alpine glaciers. International Association of Hydrological Sciences Publication 118
(Symposium at Grenoble 1975 - Isotopes and Impurities in Snow and Ice), 232-236.

Schotterer, U., W. Haeberli, W. Good, H. Oeschger, and H. Röthlisberger. 1978. Datierung von kaltem Firn und Eis in einem Bohrkern vom Colle Gnifetti, Monte Rosa Jahrb. Schweiz. Naturforsch. Ges. Wiss. Teil 1978, 48-57.

Stichler, W., D. Baker, H. Oerter, and P. Trimborn. 1983. Core drilling on Vernagtferner (Oetztal Alps, Austria) in 1979: deuterium and oxygen-18 contents. Z. Gletscherkd. Glaziologeol., 18(1), 1982, 23-35. 